\author{
Alieva Zh.M. \\ Organization of tax administration and the role of tax \\ authorities in the economic development of the region
}

Статья посвящена основным теоретическим аспектам налогового администрирования. Проведен анализ состояния системы налогового администрирования в Чеченской Республике. По результатам исследования выделены направления повышения эффективности налогового администрирования

Ключевые слова: налоговая система, налоговое администрирование, консолидированный бюджет, налоговые поступления, налоговый контроль

\section{Алиева Жанна Магамедовна}

Кандидат экономических наук, доцент

Грозненский государственный нефтяной

технический университет им. М.Д. Миллионщикова

Чеченская Республика, г. Грозный, пл.

Орджоникидзе, 100

\author{
The article deals with basic theoretical aspects of tax \\ administration. The analysis of the tax \\ administration in the Chechen Republic. The study \\ highlighted ways to improve the efficiency of tax \\ administration
}

Key words: tax system, tax administration, the consolidated budget, tax receipts, tax control

\author{
Alieva Zhanna Magamedovna \\ Candidate of Economic Sciences, Associate Professor \\ Grozny state oil technical university named M.D. \\ Millionshtchikov \\ Chechen Republic, Grozny, Ordzhonikidze sq., 100
}

Одно из важнейших условий в экономическом развитии любого государства - это обеспечение сбора налогов, надлежащей дисциплины налогоплательщиков.

Уплата налогов оказывает мощное регулирующее воздействие на жизнь общества.

Налоги, как и вся налоговая система, являются мощным инструментом управления экономикой. От того, насколько правильно построена система налогообложения, зависит эффективное функционирование всей экономики государства.

В настоящее время сложно себе представить динамичное развитие экономики и других сфер жизнедеятельности общества без существования налоговых органов. Они являются одной из наиболее эффективных и влиятельных структур государственного направления, надежной опорой власти, гарантом экономической безопасности. Налоговое ведомство обеспечивает реализацию 
экономической и социальной политики, содействует исполнению конституционных прав граждан на образование, медицинское обслуживание, выплату заработной платы, пенсий.

Налоговые органы ЧР решают поставленные перед ними задачи во взаимодействии с федеральными органами исполнительной власти, органами государственной власти субъектов Российской Федерации и органами местного самоуправления.

Чеченские налоговики играют большую роль в экономическом развитии Республики.

Проводятся мероприятия, направленные на выявление лиц, уклоняющихся от поставки на налоговый учет, налогоплательщиков незаконно извлекающих доходы от сдачи в аренду недвижимого имущества и предпринимателей, привлекающих физических лиц с нарушением трудового законодательства. Особое внимание фискальные органы отводят администрированию имущественных налогов, а также контрольной работе с задолженностью.

В числе приоритетов ФНС России определена ставка на инновационный путь развития налогового администрирования, включающий в себя модернизацию систем взаимодействия с налогоплательщиками, создание комфортных условий для исполнения налоговых обязательств с использованием современных технологий, в том числе Интернета и сотовой связи. Управление ФНС по Чеченской Республике уделяет особое внимание открытости налоговых органов и упрощению налоговых процедур, включая взаимодействие с налогоплательщиком.

В структуре Управления ФНС России по Чеченской Республике помимо аппарата Управления функционируют 5 инспекций ФНС России межрайонного уровня.

По состоянию на 01.09.2015 года в территориальных налоговых органах в Чеченской Республике состоят на учете 10608 юридических лиц, 41382 индивидуальных предпринимателя и 998412 физических лиц.

Предельная численность Управления ФНС России по Чеченской Республике 530 штатных единиц, из них: руководители - 27\%; специалисты - 73\%; мужчины - 73\%; женщины - 27\%; сотрудников моложе 30 лет - 29\%; 96\% руководителей и специалистов Управления имеют высшее образование.

В аппарат управления ФНС России по Чеченской Республике входят следующие структурные подразделения:

- отдел обеспечения Управления ФНС России по Чеченской Республике;

- отдел кадрового обеспечения и безопасности Управления ФНС России по Чеченской Республике;

- правовой отдел Управления ФНС России по Чеченской Республике;

- отдел информации и ввода данных Управления ФНС России по Чеченской Республике;

- аналитический отдел Управления ФНС России по Чеченской Республике;

- контрольный отдел Управления ФНС России по Чеченской Республике;

- отдел налогообложения Управления ФНС России по Чеченской Республике; 
- отдел обеспечения процедур банкротства Управления ФНС России по Чеченской Республике;

- отдел регистрации и учета налогоплательщиков Управления ФНС России по Чеченской Республике [1, с. 19].

Также в соответствии с возложенными на них задачами структурные подразделения Управления ФНС России по Чеченской Республике осуществляют следующую работу:

1. Отдел обеспечения Управления ФНС России по Чеченской Республике. В функции и задачи отдела обеспечения Управления входят: организация работы Управления с обращением граждан, бухгалтерский учет, материально-техническое обеспечение Управления и территориальных налоговых органов, ведение документооборота и архива Управления, освещение деятельности Управления и Межрайонных ИФНС России по Чеченской Республике в региональных и федеральных средствах массовой информации.

2. Отдел кадрового обеспечения и безопасности Управления ФНС России по Чеченской Республике. Основной задачей отдела является реализация политики и стратегии ФНС России в области государственной гражданской службы и управления персоналом в соответствии с задачами и функциями Управления и обеспечения безопасности деятельности налоговых органов.

3. Правовой отдел Управления ФНС России по Чеченской Республике. Целями и задачами правовых подразделений налоговых органов является не только защита интересов налоговых органов, но и защита прав налогоплательщиков от возможных необоснованных требований об уплате налога налоговыми органами в результате неправильного толкования норм права.

4. Отдел информации и ввода данных Управления ФНС России по Чеченской Республике. Отдел в соответствии со спецификой своей деятельности, ведет переписку по вопросам, касающимся внедрения современных информационных технологий, их формирования, настройки, обновления и т.д., с межрайонными инспекциями, министерствами, предприятиями, учреждениями и организациями РФ и ЧР, с центральным аппаратом ФНС России и ГГИВЦ ФНС России (Главный научно-исследовательский вычислительный центр).

5. Аналитический отдел Управления ФНС России по Чеченской Республике. Целью аналитического отдела является совершенствование и повышение качества аналитической работы, а также оперативно-бухгалтерского учета налогов, сборов и других обязательных платежей. Основными задачами аналитического отдела являются анализ налоговых начислений, поступлений и сводной отчетности, организация ведения оперативно-бухгалтерского учета налогов, сборов и других обязательных платежей, формирование налоговой и статистической отчетности, прогнозирование налоговых поступлений в бюджеты разных уровней, контроль исполнения установленных ФНС России индикативных показателей по мобилизации доходов в бюджетную систему.

6. Контрольный отдел Управления ФНС России по Чеченской Республике. Отдел исполняет одну из ключевых функций налоговых органов. В том числе организует контроль и надзор за соблюдением законодательства Российской 
Федерации о налогах и сборах, а также принятых в соответствии с ним нормативных правовых актов, правильностью исчисления, полнотой и своевременностью внесения налогов и сборов, а в случаях, предусмотренных законодательством Российской Федерации, - за правильностью исчисления, полнотой и своевременностью внесения в соответствующий бюджет иных обязательных платежей. Сотрудники контрольного отдела осуществляют методологическое обеспечение налогового контроля и налогового администрирования крупнейших налогоплательщиков. Проводят мониторинг, координацию и анализ деятельности налоговых органов по налоговому администрированию крупнейших налогоплательщиков. Организуют, проводят и координируют мероприятия налогового контроля в отношении налогоплательщиков, а также решают другие цели и задачи.

7. Отдел налогообложения Управления России по Чеченской Республике. Отдел налогообложения осуществляет контроль за единым применением и соблюдением налогоплательщиков, юридическими и физическими лицами, законодательства по налогам и сборам, действующих на территории Чеченской Республики. Кроме того, ведет контроль за соблюдением налогоплательщиками на территории Чеченской Республики законодательства по применения специальных налоговых режимов. Отдел занимается совершенствованием административных процедур по рассмотрению налоговых споров, утверждением начал законности в правоприменительной деятельности налоговых органов. Вместе с тем в задачи отдела входит создание условий для реализации прав налогоплательщика на рассмотрение их споров с налоговыми органами, заявлений и жалоб физических и юридических лиц на действия (бездействия) налоговых органов.

8. Отдел обеспечения процедур банкротства Управления ФНС России по Чеченской Республике. Основными задачами отдела обеспечения процедур банкротства являются урегулирование налоговой задолженности, в том числе путем принудительного взыскания и других мер, предусмотренных налоговым законодательством, и участие в реализации прав и исполнения обязанностей в деле о банкротстве и в процедурах банкротства, установленных законодательством о несостоятельности (банкротстве) и участие в обеспечении условий реализации процедур банкротства организаций - должников.

9. Отдел регистрации и учета налогоплательщиков Управления ФНС России по Чеченской Республике. Основными задачами и целями отдела регистрации и учета налогоплательщиков как самостоятельной структуры подразделения аппарата Управления Федеральной налоговой службы по Чеченской Республике являются:

- обеспечение работы и контроль формирования информационных ресурсов: Единого государственного реестра юридических лиц, Единого государственного реестра индивидуальных предпринимателей и Единого государственного реестра налогоплательщиков;

- координация деятельности налоговых органов по государственной регистрации и учету юридических и физических лиц;

- методологическое и организационное обеспечение работы и контроль: 
а) осуществления государственной регистрации юридических лиц, крестьянских (фермерских) хозяйств и физических лиц в качестве индивидуальных предпринимателей, а также их учета;

б) за открытием (закрытием) юридическими лицами и индивидуальными предпринимателями счетов в банках на территории Российской Федерации, а также за открытием (закрытием) резидентами счетов в банках;

- организация работы с налогоплательщиками.

В социально-экономическом развитии Чеченской Республики в последние годы наблюдается положительная тенденция практически по всем макроэкономическим показателям.

Важнейшим показателем общего уровня экономического развития любого региона является объем производства валового регионального продукта. Основной вклад в формирование валового регионального продукта и обеспечение его роста вносят такие виды экономической деятельности, как добыча полезных ископаемых, обрабатывающие производства, строительство, торговля, транспорт и связь, на долю которых приходится более $85 \%$ произведенного ВРП. Сельское хозяйство республики специализируется на растениеводстве и животноводстве. В структуре продукции сельского хозяйства продукция растениеводства составляет 30,2 процента, продукция животноводства - 69,8 процента. Восстанавливается рыбоводческая отрасль [2, с. 14].

Меры, предпринимаемые руководством Чеченской Республики по улучшению инвестиционного климата в регионе, дают положительные результаты. Увеличиваются объемы вкладываемых в экономику республики инвестиций, что является одним из важных показателей стабилизации обстановки в регионе и улучшения его инвестиционной привлекательности.

За 2015 год от налогоплательщиков, осуществляющих финансово-хозяйственную деятельность на территории Чеченской Республики, поступило в бюджетную систему Российской Федерации налогов и сборов, и иных обязательных платежей в сумме 9798 млн. рублей. Динамика поступлений к 2014 году составила 97,2 процента.

Снижение динамики общего объема поступлений обусловлено произведенными в 2014 году возвратами на расчетные счета крупнейшего налогоплательщика ЗАО «Дом», администрируемого межрегиональной инспекцией ФНС России №2 по крупнейшим налогоплательщикам .

Также, в 2015 году отмечено снижение на 214,2 млн. руб. или 6,9\% к уровню 2014 г. поступлений налога на добычу полезных ископаемых в виде углеводородного сырья (нефть, газ), составляющих около $30 \%$ от общего объема налоговых поступлений. Связано это со снижением в 2015 году уровня добычи нефти по сравнению с 2014 годом на 20,5\% или 207,9 тысяч тонн.

Динамика общих поступлений налогов, сборов и иных обязательных платежей в бюджетную систему РФ, без учета поступлений от крупнейших налогоплательщиков, за отчетный 2015 год, в сравнении с аналогичным показателем 2011 (докризисного) года, составила 132,9\%, прирост - 2039,1 млн. рублей.

Доходы бюджетной системы РФ в объеме поступлений за 2015 год в разрезе бюджетов сформированы следующим образом: 
- в федеральный бюджет - 2276,1 млн. руб., или 23,2\% от общих поступлений;

- в консолидированный бюджет ЧР - 7453,2 млн. руб. или 76,0\% от общих поступлений, из него:

- в региональный бюджет - 4548,9 млн. руб. или 46,4\% от общих поступлений;

- местные бюджеты - 2904,3 млн. руб. или 29,6\% от общих поступлений;

- налоги и взносы на соц. нужды - 68,7 млн. руб. или $0,7 \%$ от общих поступлений [2, с. 17].

Сбалансированность и обоснованность системы налогов и сборов имеет большое значение для республики, поскольку ни один субъект не может существовать без экономической основы, регулируемой законодательством, значительную часть которой составляет налоговая система и, следовательно, система налогов и сборов.

В настоящее время перед налоговыми органами Чеченской Республики стоят важные задачи, направленные на повышение качества налогового администрирования, собираемости налогов, а также поднятие на качественно новый уровень контрольной деятельности, сокращение объемов задолженности, мобилизация собственных доходов на основе экономического роста и развития налогового потенциала.

Главными задачами налоговых органов являются контроль за соблюдением налогового законодательства, за правильностью исчисления, полнотой и своевременностью внесения в бюджет государственных налогов и других платежей, установленных законодательством Российской Федерации.

Учитывая, что стратегической задачей республики является создание новых рабочих мест, необходимо активней проводить работу по легализации заработной платы и прибыли, добиться, чтобы каждое вновь создаваемое рабочее место в установленном законом порядке было оформлено и приносило доход республике в виде соответствующих налогов и сборов. Посредством налогов, льгот и финансовых санкций, являющихся неотъемлемой частью системы налогообложения, государство, с помощью налоговых органов, воздействует на экономическое поведение предприятий, стремясь создать при этом равные условия всем участникам общественного воспроизводства. Налоговые методы регулирования финансово-экономических отношений в сочетании с другими экономическими рычагами создают необходимые предпосылки для формирования и функционирования единого целостного рынка, способствующего созданию рыночных отношений.

Таким образом, система налоговых органов является единой и централизованной. Налоговые органы действуют не разрозненно, а совместно, находятся в тесной взаимосвязи, взаимодействии и взаимозависимости и составляют единую систему.

Единство системы налоговых органов отражает единство их сущности как органов исполнительной власти, находящихся в административном соподчинении. Это обусловлено общностью их задач и функций, которые они призваны осуществлять. Для всех налоговых органов устанавливается единый правовой 
режим их деятельности, и они нацелены на достижение общей главной цели обеспечение законности и правопорядка в налоговой сфере.

Налоговикам предстоит сложная и нужная республике работа:

- не сбавлять темпы поступлений налогов от сборов;

- сокращать накопившуюся налоговую задолженность налогоплательщиков;

- повышение доходов всех бюджетов бюджетной системы Чеченской Республики, прежде всего, за счет улучшения администрирования уже существующих налогов, а также за счет расширения налогооблагаемой базы и увеличения уровня собираемости налогов и поступления иных платежей, образующих доходную часть этих бюджетов.

- учитывая, что стратегической задачей республики является создание новых рабочих мест, добиться, чтобы каждое вновь создаваемое рабочее место в установленном законом порядке было оформлено и приносило доход республике в виде соответствующих налогов и сборов;

- обеспечение самодостаточности бюджетов. Для решения этой задачи руководством Чеченской Республики взято на усиленный контроль деятельность органов местного самоуправления Республики по увеличению налоговых и неналоговых поступлений в соответствующие бюджеты и, главным образом, по земельному и транспортному налогам и налогу на имущество физических лиц, в том числе за счет постановки на учет неучтенных объектов налогообложения, расположенных на их территориях, обеспечить формирование собственных, выверенных на основе сплошного обследования статистических показателей, обеспечивающих полноту информации о налогоплательщиках и объектах налогообложения, которые, в свою очередь, должны сверяться с данными налоговых органов. Для них это новое поле деятельности. Поэтому налоговики будут активно сотрудничать с властями на местах, делиться опытом и знаниями с избранными депутатами и совместно исполнять параметры бюджетов всех поселений.

\section{Список используемых источников:}

1. 20 лет налоговым органам России. Грозный, 2010. 15 с.

2. Аналитическая справка о работе налоговых органов Чеченской Республики по мобилизации налоговых платежей в бюджетную систему Российской Федерации за 2015 год.

(C) 2016, Алиева Ж.М.

Организация налогового администрирования и роль налоговых органов в экономическом развитии региона
(C) 2016, Alieva Zh.M.

Organization of tax administration and the role of tax authorities in the economic development of the region 